\title{
Hubungan Berat Plasenta Dengan Berat Badan Lahir Bayi di Kota Pariaman
}

\author{
Hasra Mukhlisan ${ }^{1}$, Nur Indrawaty Liputo ${ }^{2}$ Ermawati $^{3}$
}

\section{Abstrak}

Pertumbuhan janin intrauterine dipengaruhi oleh fungsi plasenta. Plasenta mensuplai oksigen dan makanan dari sirkulasi ibu ke janin dan mengeluarkan sisa metabolisme dari sirkulasi janin ke ibu. Berat plasenta bertambah akibat pertumbuhan vilus plasenta. Vilus-vilus ini berfungsi sebagai tempat pertukaran makanan, oksigen dan zat sisa janin, sehingga berat plasenta akan berperan penting dalam menentukan berat badan lahir bayi. Penelitian ini bertujuan untuk mengetahui hubungan berat plasenta dengan berat badan Iahir bayi di Kota Pariaman. Metode penelitian adalah deskriptif dan analitik, sedangkan pengolahan data dilakukan dengan uji korelasi software SPSS 15. Penelitian dilakukan di kota Pariaman dengan menggunakan data ibu melahirkan dari bulan Januari-Juni 2011. Ada 30 orang subjek dalam penelitian ini, didapatkan berat badan lahir bayi rata-rata adalah 2.996,67 gram (SD = $448,36), 4$ diantaranya (13,33\%) memiliki berat badan lahir rendah (BBLR) sementara yang lainnya normal. Berat plasenta rata-rata 496,67 gram $(S D=49,01)$. Berdasarkan hasil uji korelasi, berat plasenta berhubungan dengan berat badan lahir bayi di Kota Pariaman dengan $p=0,00 \quad(<0,05)$ dan $r=0,784$. Kesimpulan dari penelitian ini adalah berat plasenta memiliki hubungan yang bermakna dengan berat badan lahir bayi di Kota Pariaman dan kekuatan hubungan sedang.

Kata kunci: Plasenta, berat plasenta, berat badan lahir bayi

\begin{abstract}
The intrauterine growth of foetus is affected by the placental function. The functions are supplying oxygen and nutrition from maternal circulation to the foetus and secreting the metabolism residual from foetus circulation to the maternals. The increase of placental and foetus weight occurs in the same time. The villi is the surface for the exchange of nutritions, oxygens, and residual substances of feotus. The goals of this study is to identify the relationship between placental weight and birth weight in Pariaman. The method of this study is descriptive and analytical with correlation test and SPSS 15 was used for data processing. This study was held in Pariaman and pregnant woment's data taken from January until June 2011. The results of this study showed that 30 subjects had the average of birth weight was 2,996.67 gram (SD = 448.36), $4(13.33 \%)$ were low birth weight, while the others were normal. The average of placental weight was $496.67 \mathrm{gram}(S D=49.01)$. Based on correlation test, placental weight had relationship with birth weight in Pariaman $(p=0.00(<0.05)$ and $r=0.784)$. The conclusion is placental weight had significant correlation with birth weight in Pariaman and the power of correlation was intermediate.
\end{abstract}

Keywords:Placenta, placental weight, birth weight

Affiliasi penulis : ${ }^{1}$ Mahasiswa FK Unand, ${ }^{2}$ Bagian Gizi FK Unand, ${ }^{3}$ Bagian Obgyn FK Unand.

Korespondensi : Fakultas Kedokteran Universitas Andalas Jl.Perintis Kemerdekaan No.94, Padang. Telp: 075131746

\section{Pendahuluan}

Berat badan lahir merupakan salah satu indikator kesehatan bayi baru lahir. Besar kecilnya berat badan lahir tergantung bagaimana pertumbuhan janin intrauterine selama kehamilan. Bayi yang dilahirkan aterm (37 sampai 42 minggu) memiliki berat badan normal $2.500-4.000$ gram. Beberapa faktor dapat mempengaruhi berat badan lahir bayi yang terdiri dari faktor dari ibu, faktor janin, dan faktor plsenta. Faktor dari ibu adalah di antaranya nutrisi, berat badan, usia, paritas, dan ibu yang merokok. Variasi berat badan lahir juga berasal dari bayi sendiri di antaranya perbedaan jenis kelamin, adanya kelainan genetik tertentu, dan bayi kembar. Selain itu yang terpenting adalah plasenta yang juga memiliki peran penting dalam menentukan berat badan lahir bayi karena merupakan tempat pertukaran zat gizi dari ibu untuk janin. ${ }^{2,3}$

Plasenta berperan dalam menentukan berat lahir bayi melalui kontribusinya yang sangat penting bagi pertumbuhan janin intrauterine. Dalam kehamilan, fungsi utama plasenta adalah sebagai organ penyalur bahan-bahan makanan dan oksigen yang diperlukan oleh janin dari darah ibu ke dalam darah janin dan juga mengadakan mekanisme pengeluaran produkproduk ekskretoris dari janin kembali ke ibu. ${ }^{4}$ Plasenta yang normal akan mampu melaksanakan fungsi tersebut dalam menunjang pertumbuhan janin. Plasenta normal pada saat aterm berbentuk seperti cakram berwarna merah tua dengan berat sekitar 500 sampai 600 gram, diameter 15 sampai $25 \mathrm{~cm}$ ( \pm 7 inci) dan tebal sekitar $3 \mathrm{~cm}$, akan tetapi ukuran ini bervariasi tergantung bagaimana plasenta disiapkan. ${ }^{5,7}$

Pertumbuhan dan perkembangan janin selama kehamilan sangat bergantung kepada keutuhan dan kelancaran suplai vaskular uteroplasenta. Suplai uteroplasenta yang terganggu akan menyebabkan gangguan fungsi plasenta dalam menyalurkan bahan makanan dan nutrisi yang diperlukan bagi janin. Sekitar dua puluh lima sampai tiga puluh persen gangguan pertumbuhan pada janin disebabkan oleh penurunan aliran darah uteroplasenta pada kehamilan dengan komplikasi penyakit vaskular ibu. $^{8}$ Bayi dengan gangguan pertumbuhan seperti Berat Badan Lahir Rendah atau BBLR (<2.500 gram) memiliki risiko mortalitas yang tinggi dan menyebabkan masalah kesehatan bayi baru lahir. ${ }^{9}$

Selama proses pertumbuhan janin, plasenta juga mengalami pertumbuhan yang terlihat dari 
pertambahan luas dan ketebalannya akibat pembentukan cabang-cabang dari vilus yang akan mencapai luas permukaan antara $4-14 \mathrm{~m}^{2}$. Bertambahnya luas dan ketebalan plasenta ini akan menambah berat plasenta. Hal tersebut memperlihatkan bahwa salah satu variabel dalam menentukan efektifitas plasenta sebagai organ penyalur adalah berat plasenta karena berat plasenta mencerminkan luas daerah yang tersedia untuk pertukaran melewati epitel trofoblas vilus yang mengalami pertumbuhan tadi. ${ }^{10}$

Dari kenyataan di atas, ukuran plasenta terutama berat plasenta dapat menunjukkan keadaan pasokan nutrisi dan oksigen ke janin. Plasenta yang berat atau mengalami hipertrofi, mungkin menunjukkan adanya respon adaptif terhadap lingkungan intrauterin yang buruk. ${ }^{11,12}$ Sebaliknya, plasenta yang kecil mungkin menunjukkan distribusi zat makanan ke plasenta yang buruk yang mengakibatkan gangguan pertumbuhan plasenta. ${ }^{11}$

Terdapat beberapa penelitian yang telah dilakukan mengenai hubungan plasenta dengan berat badan lahir bayi, namun dalam tingkat yang lebih luas (di Sumatra Barat, khususnya di Kota Pariaman) belum banyak penelitian tentang hal ini. Rivai (2007) dalam penelitiannya mendapatkan hubungan yang bermakna antara berat plasenta dengan berat badan lahir bayi. Begitu juga dengan penelitian yang dilakukan oleh Pathaket al. (2010). ${ }^{13}$

Berdasarkan hal diatas, maka penelitian ini bertujuan untuk mengetahui hubungan antara berat plasenta dengan berat badan lahir bayi di Kota Pariaman.

\section{Metode}

Penelitian dilakukan di kota Pariaman pada bulan Oktober 2011 sampai September 2012. Subjek dalam penelitian ini sebanyak 30 orang. Subjek merupakan ibu hamil yang melahirkan dengan bantuan bidan yang telah bekerja sama dalam penelitian Prof. dr. Nur Indrawaty Lipoeto, M.Sc., Ph.D., Sp.GK dan kawan-kawan di kota Pariaman pada bulan Januari-Juni 2011 yang memenuhi kriteria inklusi dan tidak memiliki kriteria eksklusi. Teknik pengambilan subjek adalah dengan simple random sampling.Instrument penelitian yang digunakan adalah timbangan untuk mengukur berat plasenta dan berat badan lahir bayi (merek baby scale) yang mempunyai ketelitian $0,1 \mathrm{~kg}$, baki tempat plasenta dan kuesioner untuk pengisian identitas responden. Data yang diperoleh diolah dengan software computer yaitu SPSS 15, dan untuk analisis hasil penelitiannya digunakan uji korelasi dengan tingkat pemaknaan $p<$ 0,05 .

\section{HasildanPembahasan}

\section{a. Berat Plasenta}

Tabel 1: Distribusi frekuensi subjek penelitian berdasarkan berat plasenta

\begin{tabular}{ccrc}
\hline $\begin{array}{c}\text { BeratPlasenta } \\
\text { (gram) }\end{array}$ & Mean \pm SD & $\boldsymbol{f}$ & $\begin{array}{c}\text { Persentase } \\
(\%)\end{array}$ \\
\hline$<500$ & $400 \pm 0$ & 4 & 13,33 \\
$500-600$ & $511,54 \pm 32,58$ & 26 & 86,67 \\
\hline Total & $496,67 \pm 49,01$ & 30 & 100
\end{tabular}

Berdasarkan tabel di atas didapatkan 4 subjek penelitian dengan berat plasenta $<500$ gram $(13,33 \%)$ dengan berat rata-rata 400 gram dan 26 subjek atau $86,67 \%$ memiliki berat plasenta normal 500 - 600 gram dengan rata-rata 511,54 gram ( \pm $32,58 \mathrm{SD})$. Secara keseluruhan rata-rata berat plasenta yang didapatkan dalam penelitian ini adalah 496,67 ( $\pm 49,01$ SD).

\section{b. Berat Badan Lahir Bayi}

Tabel 2: Distribusi frekuensi subjek penelitian berdasarkan berat badan lahir bayi

\begin{tabular}{crrr}
\hline $\begin{array}{c}\text { Berat Badan } \\
\text { Lahir Bayi } \\
\text { (gram) }\end{array}$ & Mean \pm SD & $\boldsymbol{f}$ & $\begin{array}{c}\text { Persentase } \\
(\%)\end{array}$ \\
\hline$<2.500$ & $2.175 \pm 206,15$ & 4 & 13,33 \\
$2.500-4.000$ & $3.123,08 \pm 321,63$ & 26 & 86,67 \\
\hline Total & $2.996,67 \pm 448,36$ & $\mathbf{3 0}$ & $\mathbf{1 0 0}$ \\
\hline
\end{tabular}

Berdasarkan tabel diatas bayi dengan berat badan lahir rendah $(<2.500$ gram) didapatkan sebanyak 4 bayi $(13,33 \%)$ dengan berat rata-rata 2.175 gram $( \pm$ 206,15 SD) sedangkan bayi dengan berat badan normal (2.500 - 4.000 gram) adalah 26 bayi atau $86,67 \%$ dengan berat rata-rata $3.123,08$ gram $( \pm$ $321,63 \mathrm{SD})$. Secara keseluruhan berat badan lahir bayi rata-rata yang didapatkan adalah 2.996,67 gram ( \pm 448,36 SD).

\section{c. Hubungan Berat Plasenta dengan Berat Badan Lahir Bayi}

Tabel 3: Hasil analisis hubungan berat plasenta dengan berat badan lahir bayi

\begin{tabular}{lcc}
\hline $\begin{array}{c}\text { Pertumbuhan janin } \\
\text { intrauterine }\end{array}$ & $\begin{array}{c}\text { Berat Badan Lahir } \\
\text { Bayi }\end{array}$ \\
\hline Beratplasenta & $\mathbf{R}$ & $\boldsymbol{p}$ \\
\cline { 2 - 3 } & $+0,784$ & 0,00 \\
\hline
\end{tabular}

Dari table diatas dapat dilihat bahwa hasil analisis uji statistic menggunakan uji korelasi Pearson pada penelitian ini didapatkan nilai koefisien korelasi Pearson ( $r)$ sebesar $+0,784$, yang menunjukkan derajat hubungan sedang dengan tarif signifikansi $(p)$ $0,00(p<0,05)$. Dari hasil analisis uji statistik tersebut dapat disimpulkan bahwa terdapat hubungan yang bermakna antara berat plasenta dengan berat badan lahir bayi.

Hasil penelitian ini tidak jauh berbeda dengan hasil yang didapatkan oleh Rivai (2007) tentang hubungan berat plasenta dengan berat badan lahir bayi yaitu $r=0,847$ dan $p<0,05 .^{14} \mathrm{Hal}$ ini sesuai dengan teori bahwa salah satu penentu utama berat badan lahir bayi adalah berat plasenta karena makanan dan oksigen di distribusikan dari ibu ke janin melalui plasenta. ${ }^{4}$ Plasenta akan bertambah luas dan berat seiring pertambahan masa kehamilan akibat bertambahnya jumlah vilus. Sedangkan vilus ini merupakan bagian yang penting dalam pertukaran makanan dan oksigen serta zat-zat sisa janin. Jika 
vilus makin luas, maka daerah pertukaran akan semakin luas untuk menunjang kehidupan janin. ${ }^{10}$

\section{Kesimpulan}

Berdasarkan penelitian yang telah dilakukan, dapat ditarik kesimpulan bahwa :

1. Sebagian besar berat badan lahir bayi di Kota Pariaman adalah dalam rentang normal.

2. Sebagian besar berat plasenta dari ibu yang melahirkan di Kota Pariaman adalah dalam rentang normal.

3. Terdapat hubungan yang bermakna antara berat plasenta dengan berat badan lahir bayi di Kota Pariaman.

\section{Daftar Pustaka}

1. Cunningham FG, dkk. Obstetri dalam perspektif luas. Dalam : Hartono H dkk (editor). Obstetri Williams. Edisi ke-21. Vol 1. Jakarta: EGC; 2006. hlm. 3 - 5 .

2. Cunningham FG dkk. Gangguan pertumbuhan janin. Dalam : (terjemahan) Hartono $\mathrm{H}$ dkk (editor). Obstetri Williams. Edisi ke-2. Vol 1. Jakarta: EGC; 2006. hlm. 841 - 5.

3. Hall JG. Abnormalitas klinik karena kromosom Dalam: (terjemahan) Nelson WE dkk (editor). Buku teks ilmu kesehatan anak Nelson. Edisi ke-15. Vol. 1, Jakarta: EGC; 2000. hlm. 389 99.

4. Guyton AC, Hall JE. Kehamilan dan Laktasi. Dalam: Rachman LY dkk (editor). Buku ajar fisiologi kedokteran. Edisi ke-11. Jakarta: EGC; 2008. hlm. 1082-9.

5. Cunningham FG dkk. Plasenta dan membran janin. Dalam: (terjemahan) Hartono $\mathrm{H}$ dkk (editor). Obstetri Williams. Edisi ke-21. Vol 1. Jakarta: EGC; 2006. hlm. 100 - 4.

6. Sadler TW. Minggu ketiga hingga lahir: janin adan plasenta. Dalam: (terjemahan) Novrianti A (editor). Embriologi Kedokteran Langman. Edisi ke-10. Jakarta: EGC; $2010 \mathrm{hlm} .103-27$

7. Sloane E. Sistem reproduksi, kehamilan dan perkembangan. Dalam: Widyastuti $\mathrm{P}$ (editor) Anatomi dan Fisiologi untuk Pemula. Jakarta: EGC; 2004. hlm. 367-8.
8. Damanik SM. Klasifikasi bayi menurut berat lahir dan masa gestasi. Dalam : Kosim MS, Ari Y, Rizalya D, Gatot IS, Ali U. Buku ajar neonatologi. Edisi ke-1. Jakarta : Ikatan Dokter Anak Indonesia; 2010. hlm. 11-29.

9. Kliegman RM. Bayi beresiko tinggi. Dalam: (terjemahan) Behrman RE, Robert K, Ann MA Ilmu kesehatan anak Nelson. Edisi ke- 15 vol 1. Jakarta : EGC; 2000. hlm. 558-73.

10. Cunningham FG dkk. Petumbuhan dan perkembangan janin. Dalam: Hartono $\mathrm{H}$ dkk (editor). Obstetri Williams. Edisi ke-21. Vol 1. Jakarta: EGC; 2006. hlm. 146 - 9.

11. Baptiste-Roberts K, Salafia CM, Nicholson WK, Duggan A, Wang NY, Brancati FL. Maternal risk factors for abnormal placental growth: The National Collaborative Perinatal Project. BioMed Central Pregnancy and Childbirth. 2008 : 8-44.

12. Tegethoff $M$, Greene $N$, Olsen J,Meyer $A H$, Meinlschmidt G. Maternal psychosocial stress during pregnancy and placenta weight: Evidence from a National Cohort Study. PLoS One. 2010; 5(12): e14478.

13. Pathak S, Jessop F, Hook L, Sebire NJ, Lees CC. Placental weight, digitally derived placental dimensions at Term and Their Relationship to Birth Weight. The Journal of Maternal-Fetal and Neonatal Medicine. 2010; 23(10): 1176-82.

14. Rivai LM. Hubungan berat plasenta dengan berat badan lahir bayi pada persalinan aterm (Skripsi) Padang: Fakultas Kedokteran Universitas Andalas; 2007. hlm 24-8. 